\title{
Evaluating the policy approach towards the undeclared economy in FYR Macedonia
}

\section{Colin C. Williams*, Rositsa Dzhekova, Josip Franic and Lyubo Mishkov}

Sheffield University Management School (SUMS), University of Sheffield, Conduit Road, Sheffield, S10 1FL, UK

Email: C.C.Williams@sheffield.ac.uk Email: rndzhekova1@sheffield.ac.uk Email: jfranic1@sheffield.ac.uk Email: lrmishkov1@sheffield.ac.uk *Corresponding author

\begin{abstract}
This paper evaluates how the undeclared economy is being tackled in FYR Macedonia. Reporting the findings on the extent and nature of the undeclared economy in this country, FYR Macedonia is shown to have the largest undeclared economy of all European countries and such work is prevalent across all sectors and business types. Examining how the undeclared economy is being tackled, it is revealed that there is a need not only to move away from the current fragmented approach by establishing a single agency or committee to better coordinate the fight against undeclared work in FYR Macedonia but also for a shift away from the current focus upon deterrents and for more attention to be paid to a wider range of measures that enable undeclared work to move into the declared economy. Unless such an approach is pursued then it is likely to remain difficult to make further headway in tackling undeclared work.
\end{abstract}

Keywords: informal sector; shadow economy; entrepreneurship; tax evasion; economic development; public policy; Macedonia.

Reference to this paper should be made as follows: Williams, C.C., Dzhekova, R., Franic, J. and Mishkov, L. (2015) 'Evaluating the policy approach towards the undeclared economy in FYR Macedonia', Int. J. Entrepreneurship and Small Business, Vol. 24, No. 2, pp.268-286.

Biographical notes: Colin C. Williams is a Professor of Public Policy in Sheffield University Management School (SUMS) at the University of Sheffield in the UK. His research interests include the informal economy, entrepreneurship and economic development, subjects on which he has published some 20 monographs and over 300 journal articles over the past 25 years. His recent books include Confronting the Shadow Economy (2014, Edward Elgar), The Shadow Economy (2013, Institute of Economic Affairs) and Informal Work in Developed Nations (2010, Routledge).

Rositsa Dzhekova is a Marie Curie Fellow at the Sheffield University Management School (SUMS) at the University of Sheffield. She is normally employed at Vitosha Research Ltd in Bulgaria and currently on secondment at Sheffield funded by the European Commission's Industry-Academia Partnerships Programme (IAPP). 
Josip Franic is a Marie Curie Fellow and a doctoral research student in the Sheffield University Management School (SUMS) at the University of Sheffield studying the undeclared economy in Croatia. $\mathrm{He}$ is normally employed at the Institute of Public Finance in Croatia and currently on secondment at Sheffield funded by the European Commission's Industry-Academia Partnerships Programme (IAPP).

Lyubo Mishkov is a Marie Curie Fellow and a doctoral research student in the Sheffield University Management School (SUMS) at the University of Sheffield studying the undeclared economy in Bulgaria, and is currently on secondment at Vitosha Research Ltd in Bulgaria funded by the European Commission's Industry-Academia Partnerships Programme (IAPP).

\section{Introduction}

In recent decades, a burgeoning literature has revealed the persistence and even growth of the undeclared economy in a multifarious array of countries across the world (Dana, 1998, 2010, 2013; Hudson et al., 2012; International Labour Organisation, 2012; Rezaei et al., 2013a, 2013b, 2014; Schneider et al., 2010; Williams, 2007a, 2007b, 2011, 2014a, 2014b, 2014c, 2014d, 2014e; Williams and Gurtoo, 2013; Williams and Nadin, 2011a, 2011b; Williams and Round, 2010; Williams et al., 2010, 2013b). Indeed, this tendency of people and businesses to earn monetary income that they do not declare to the state for tax, social security and/or labour law purposes has been widely recognised to not only lower work quality standards and create risks for the health and safety of workers, but also to act as a brake on economic growth, put at greater risk the financial sustainability of social protection systems and undermine the legitimate business environment through unfair competition (European Commission, 2007; Gallin, 2001; Vanderseypen et al., 2013). The result is that greater attention has started to be paid to how this undeclared economy can be tackled (Dekker et al., 2010; Dzhekova and Williams, 2014; Franic and Williams, 2014). To contribute to this literature, the aim of this paper is to provide an evaluation of the policy approach towards the undeclared economy in FYR Macedonia.

Firstly, therefore, this paper provides a baseline assessment of the extent and nature of the undeclared economy in FYR Macedonia. Secondly, the institutional infrastructure for tackling undeclared work in this country is reviewed and thirdly, the policy approach and measures currently adopted for tackling the undeclared economy. Finding that there is a fragmented approach with no one single agency or central committee being responsible for coordinating the fight against undeclared work in FYR Macedonia and that only a narrow range of policy measures are currently adopted for tackling the undeclared economy, the fourth and final section of this paper concludes by calling for a more coordinated approach and a shift away from the current focus upon deterrence and towards an approach and measures that more effectively enable undeclared work to move into the declared economy.

Before commencing, however, the undeclared economy needs to be defined. Although in many developing countries, enterprise-based and jobs-based definitions have been widely used (see Williams, 2013a, 2014c; Williams and Lansky, 2013), in 
developed economies it has been activity-based definitions that have been more commonly used to define the scope of the undeclared economy. The most widely used activity-based definition, and the one adopted in this paper, defines the undeclared economy as:

\begin{abstract}
"all legal production activities that are deliberately concealed from public authorities for the following kinds of reasons: to avoid payment of income, value added or other taxes; to avoid payment of social security contributions; to avoid having to meet certain legal standards such as minimum wages, maximum hours, safety or health standards, etc.” [OECD, (2002), p.139]
\end{abstract}

This definition has been widely adopted in Europe and other advanced economies (see European Commission, 2007; Vanderseypen et al., 2013; Williams, 2014b, 2014e; Williams and Round, 2007, 2009). The only absence about this production relative to the declared economy is that the activities are not declared to the authorities for tax, social security and/or labour law purposes. As such, illegal (criminal) activities are excluded, as are unpaid forms of work. In FYR Macedonia, a similar definition is used by the Public Revenue Office who define the undeclared economy as "all economic activities which are legal but unofficial and undeclared for tax purposes, from individuals, unofficial groups and organizations" [Risteski, (2009), p.1].

Figure 1 The size of the undeclared economy in European countries in 2007 (\% of GDP)

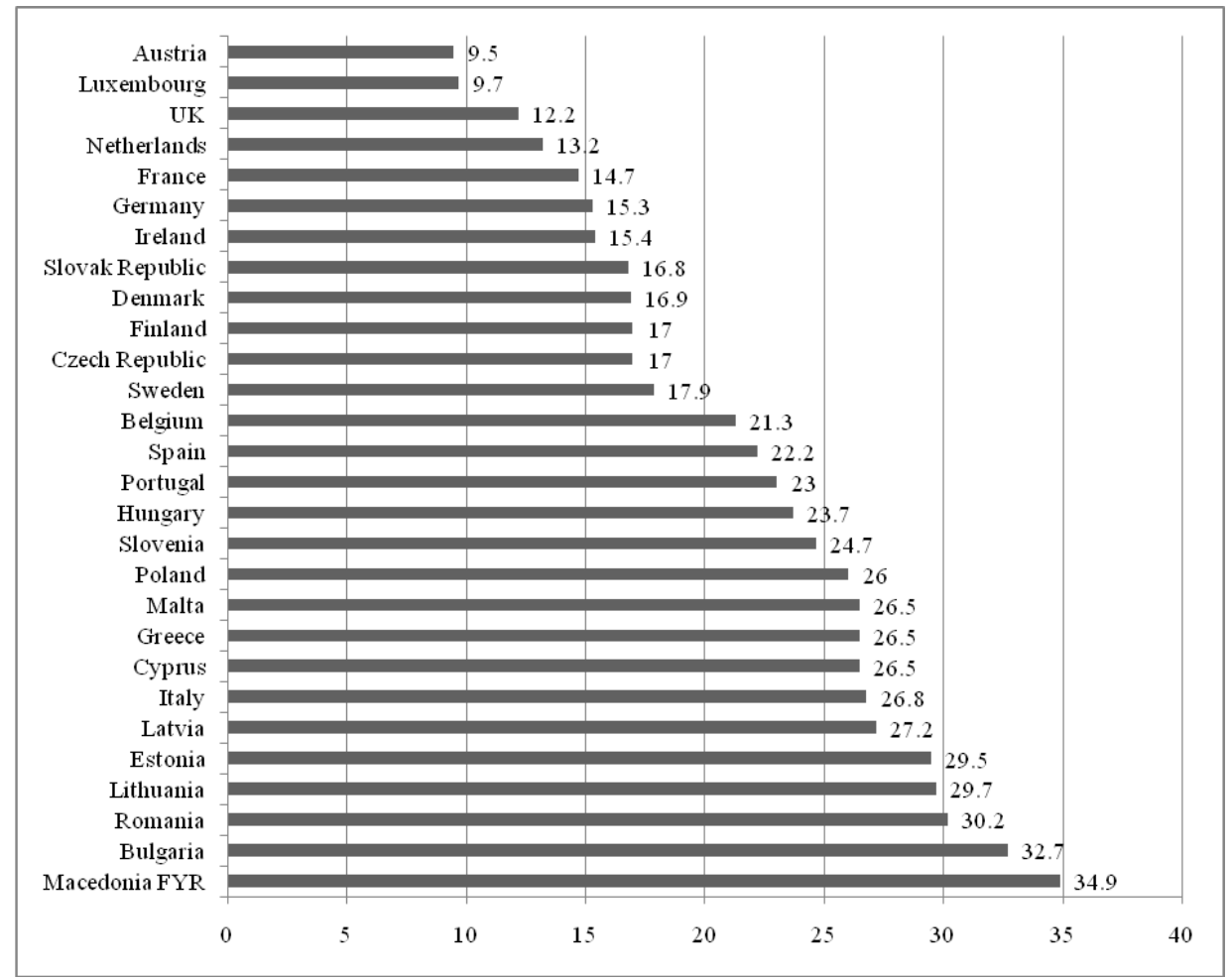

Source: Derived from Schneider et al. (2010) 


\section{Extent and nature of the undeclared economy in FYR Macedonia}

Various methods exist for measuring the size of the undeclared economy. These range from indirect measurement methods which use proxy indicators and/or seek indications of its size in data collected for other purposes, through to direct survey methods (Garvanlieva et al., 2012; Risteski, 2009; Stankovic and Stankovic, 2012). The most commonly used indirect survey method is the multiple indicators multiple causes (MIMIC) method of Schneider et al. (2010). As Figure 1 reveals, this finds that the undeclared economy in FYR Macedonia is the equivalent of $35 \%$ of GDP, which means that it is larger than in any other European Union member state. As such, the problem of undeclared work in FYR Macedonia is more acute than in other European countries.

To analyse whether the undeclared economy is growing or declining in FYR Macedonia, Table 1 reports the results of different studies which all use indirect measurement methods. This reveals that whichever measurement method is employed, the finding is that the undeclared economy in FYR Macedonia is gradually decreasing in size over the past decade or so. Similar trends of gradual decline are identified in most other European countries (Williams, 2014c, 2014d).

Table 1 Changing size of the undeclared economy in FYR Macedonia, 2000-2011

\begin{tabular}{lcccc}
\hline & $\begin{array}{c}\text { Two-sector dynamic } \\
\text { general equilibrium model } \\
\text { (Elgin and Oztunali, 2012) }\end{array}$ & $\begin{array}{c}\text { Electricity consumption } \\
\text { (Garvanlieva } \\
\text { et al., 2012) }\end{array}$ & $\begin{array}{c}\text { MIMIC } \\
\text { (Garvanlieva } \\
\text { et al., 2012) }\end{array}$ & $\begin{array}{c}\text { MIMIC } \\
\text { (Schneider al., 2010) }\end{array}$ \\
\hline 2000 & 35.10 & 34.10 & - & 38.2 \\
2001 & 34.86 & 33.23 & - & 39.1 \\
2002 & 34.97 & 31.49 & - & 38.9 \\
2003 & 35.06 & 34.22 & 34.22 & 38.4 \\
2004 & 34.80 & 32.75 & 44.44 & 37.4 \\
2005 & 34.89 & 32.67 & 40.18 & 36.9 \\
2006 & 34.97 & 31.02 & 41.32 & 36 \\
2007 & 34.90 & 28.14 & 52.48 & 34.9 \\
2008 & 34.39 & 25.16 & 50.39 & - \\
2009 & - & 23.38 & 41.58 & - \\
2010 & - & 24.01 & 40.46 & - \\
2011 & - & - & 46.99 & - \\
\hline
\end{tabular}

This finding that there is a gradual decline in the size of the undeclared economy in FYR Macedonia is further reinforced when the results of various direct surveys are analysed. On the one hand, the Labour Force Survey conducted by the State Statistical Office of the FYR Macedonia indicates that in 2012, 22.5\% of all employed were engaged in informal employment compared with $25 \%$ in $2011,26 \%$ in $2010,27 \%$ in 2009 and $29 \%$ in 2008 (State Statistical Office, 2013). On the other hand, the World Bank Enterprise Survey for FYR Macedonia identifies that in 2013, 55.6\% of firms reported that they compete against firms operating on an undeclared basis, which is a considerable decline from 2009 when $73.9 \%$ of firms faced such competition. There is also a decline in the share of firms which identify that the practices of undeclared competitors represent a major constraint 
on the growth of their business, from $55 \%$ in 2009 to $35 \%$ in 2013 . These figures, nevertheless, remain higher than for all other EU Member States.

Whichever method is used to measure the size of the undeclared economy therefore, the finding is that the undeclared economy is larger in FYR Macedonia than in most, if not all, other European countries. However, it is declining in size in FYR Macedonia over time, akin to other European countries.

Turning to the nature of the undeclared economy, the first issue to consider is whether there are variations in its size across various sectors and business types. As Table 2 displays, which reports the findings of the World Bank Enterprise Survey 2013 so far as FYR Macedonia is concerned, the finding is that manufacturing businesses are more likely that those in retail or services to face competition from unregistered firms. At the same time, formal retail businesses are more likely to perceive such unfair competition as a major constraint to conducting business in the country. Medium-size enterprises (20-99 employees) are also more likely to face competition from those operating in the undeclared economy, followed by small firms. Domestic firms located in South Macedonia are also more affected by the practices of undeclared competitors.

Table 2 Extent of undeclared practices in FYR Macedonia, 2013: by sector, firm size and location

\begin{tabular}{lcc}
\hline Type of business & $\begin{array}{c}\text { \% of firms competing } \\
\text { against unregistered } \\
\text { or informal firms }\end{array}$ & $\begin{array}{c}\text { \% of firms identifying practices of } \\
\text { competitors in the informal sector } \\
\text { as a major constraint }\end{array}$ \\
\hline By sector: & 66.3 & 35.5 \\
$\quad$ Manufacturing & 54.0 & 39.8 \\
Retail & 51.5 & 31.6 \\
Other services & & \\
By firm size: & 52.8 & 33.0 \\
Small (5-19) & 75.6 & 46.8 \\
Medium (20-99) & 35.0 & 19.5 \\
Large (100+) & & 18.5 \\
By location: & 38.4 & 37.6 \\
Eastern Macedonia & 60.2 & 36.8 \\
North-West and West Macedonia & 56.7 & 45.8 \\
Skopje & 70.7 & \\
South Macedonia & & 37.1 \\
By ownership type: & 58.9 & 2.6 \\
Domestic & 12.1 & \\
10\%+ foreign ownership & & \\
\hline
\end{tabular}

Source: World Bank Enterprise Survey 2013 (World Bank, 2014)

Examining the types of undeclared work conducted, an OECD study finds that one of the main types of undeclared activity is the under-reporting of economic activity to avoid paying turnover taxes, import duties, personal income and labour taxes (Ahmad, 2007). Within misreporting practices, under-reported salaries ('envelope wages') are a significant aspect (see Williams, 2009, 2013b; Williams and Padmore, 2013a, 2013b). Other common types of misreporting in the non-financial and household sectors include 
over-reported intermediate consumption, non-registered employment and non-registered sales in trade (UNECE, 2008). This is similarly the situation elsewhere in Europe (Williams and Martinez, 2014a, 2014c, 2014d).

Stankovic and Stankovic (2012) and Tevdoski (2011), meanwhile, note that undeclared work is particularly prevalent in relation to seasonal jobs, temporary or parttime work and affects mostly those with low educational qualification levels, as well as low earners. Examining the level of undeclared jobs within non-standard employment (part-time, fixed-term and own-account jobs/self-employed) based on data from the Labour Force Survey of the State Statistical Office, moreover, Novkovska $(2008,2013)$ finds that in $2007,77 \%$ of undeclared waged work was non-standard and temporary employment, while only $11 \%$ of declared waged employment was non-standard and temporary. Indeed, further analysis of the Labour Force Survey reveals that the age groups most likely to engage in undeclared work are young people aged $15-24$ (40\% of all employed in that age group participate in the undeclared economy), as well as those older than 65 years (over $85 \%$ of all employed from that age group). Analysing gender variations, the survey reveals that men are slightly more likely to work in the undeclared economy than women $(23.3 \%$ of men compared to $21.3 \%$ of women for 2012 (State Statistical Office, 2013).

With respect to own-account work (self-employment), the International Labour Organisation's Labour Force Survey conducted in 2010 shows that $34.7 \%$ of non-agricultural self-employment is undeclared, with $48.6 \%$ of all sole traders (own-account enterprise owners) operating on an undeclared basis (International Labour Organisation, 2011a). This is a similar level to other countries and displays the existence of a large hidden enterprise culture in FYR Macedonia (Williams, 2007a, 2007b, 2013a; Williams and Round, 2007, 2009; Williams and Yousseff, 2014). The share of undeclared self-employment is much higher in rural areas, where $44.8 \%$ of the self-employment is undeclared compared to $28.3 \%$ in urban areas. When it comes to dependant wage employment meanwhile, the survey reveals that $9.2 \%$ is undeclared wage employment (21.4\% of agricultural employees and $8.8 \%$ of employees in all other sectors). Undeclared wage employment is higher in rural areas where $14.5 \%$ of all wage employees are undeclared, while in urban areas only $6.9 \%$ of waged employment is undeclared.

Given this overview of the extent and nature of the undeclared economy in FYR Macedonia, attention now turns to an evaluation of how undeclared work is being tackled by examining firstly, the institutional infrastructure and secondly, the policy approaches and measures being adopted.

\section{Institutional infrastructure for tackling undeclared work}

A 2010 study of 31 European countries (Dekker et al., 2010) reveals that eight countries (26\%) have either a single agency responsible for the fight against undeclared work or central coordinating committee responsible for ensuring coordinated action by the multifarious departments involved in tackling undeclared work. Furthermore, the study found that there are three main pillars where the authorities' efforts are focused: labour, social security and taxes (Table 3). FYR Macedonia, similar to other transition countries in Central and Eastern Europe, belongs to the group of countries where the main focus in tackling undeclared work is on labour law violation. Although there is no single body 
responsible for coordinating the fight against undeclared work, the labour inspectorate within the Ministry of Labour and Social Policy (MLSP) is the lead agency when it comes to combating undeclared work.

Table 3 Undeclared work policies in Europe: focus on three pillars

\begin{tabular}{lcc}
\hline Focus on labour & Focus on social security & Focus on taxes \\
\hline Bulgaria & Belgium & Austria \\
Cyprus & France & Denmark \\
Czech Republic & Switzerland & Estonia \\
Greece & Liechtenstein & Germany \\
Hungary & & Finland \\
Italy & Ireland \\
Iceland & & Netherlands \\
Latvia & Norway \\
Lithuania & Sweden \\
Malta & UK \\
Luxembourg & \\
Poland & \\
Portugal & \\
Romania & \\
Slovakia & \\
Slovenia & \\
Spain & \\
\hline
\end{tabular}

Source: Dekker et al. (2010)

In FYR Macedonia, although the labour inspectorate within the MLSP is the lead agency, many other government departments and agencies are responsible for different aspects of the fight against undeclared work. Indeed, the MLSP, develops drafts of legislation, proposes programmes and measures related to labour market regulation, including in the field of tackling undeclared work. As such, the MLSP implements state policy through its specialized units, namely the Employment Agency, State Labour Inspectorate, Social Assistance Agency and their regional structures. It regulates the activity of labour market institutions at national and regional level. It also participates in the development of the main parameters of social security and payments related to it. Besides this Ministry, others with responsibility include the Ministry of Finance and Public Revenue Office, the Public Revenue Office which is responsible for detecting tax non-compliance, the Ministry of Economy(which includes the State Market Inspectorate, State Inspectorate for Technical Inspection and State Inspectorate for Construction and Urban Development) which is responsible for amongst other things strengthening control over undeclared commercial activities, and the Customs Administration and Ministry of Interior responsible for border control, including 'shuttle trade'.

At present however, the coordination between the State Labour Inspectorate and other enforcement agencies remains limited, judging by the lack of formal coordination procedures and joined-up strategies, as well as the lack of common targets across 
different departments (Williams et al., 2013a). Joint inspections take place mainly in the field of safety at work, and increasingly within tax collection campaigns (between the labour inspectorate and the Public Revenue Office). Some efforts are underway to implement network software enabling the labour inspectorate to access relevant data from other institutions, such as the Central Registry (commercial register), the Public Revenue Office and the Employment Agency, among others. Nevertheless, there is little in the way of shared strategies and targets.

Turning to the role of social partners, there is also room for improvement in terms of their involvement in decision-making with regard to tackling the undeclared economy. While during the 1980s the trade union density (trade union members as percentage of all employees in dependent employment) in FYR Macedonia amounted to $97 \%-98 \%$ (due to fact that all employees were members of a trade union during socialism), this density was only about $28 \%$ in 2010 (Eurofound, 2012). A possible reason for this drop is the general lack of public trust in trade unions, which are not seen as important social actors. They are also seen as close to the political elites and unable to promote and protect the interests of employees. Trade unions have often publicly supported political parties and their election candidates. In 1998 some union leaders were even nominated as left-oriented political party candidates in the parliamentary elections. A similar lack of trust exists when it comes to the main employers' organisation, whose density was also below $24 \%$ in 2010 (Eurofound, 2012). Indeed, there is only one employers' organisation that meets the national representativeness criteria, namely the Employers' Organisation of Macedonia (EOM), which covers about $23 \%$ of the private sector employees.

Bipartite and tripartite social dialogue at present occurs mainly through the Economic and Social Council (ESC), a consultative body established in 1996. The Government is represented by the Ministries of Labour, Economy, Finance and the deputy prime minister. The trade unions participating in the ESC are the Federation of Trade Unions of Macedonia and the Confederation of Free Trade Unions of Macedonia, while the only representative of employers participating in the ESC is the Employers Organization of Macedonia. Each social partner has four members in the ESC, with the Minister of Labour acting as the Council's president (there is no rotation principle). The powers of the current ESC were reinforced in September 2010 through a new agreement for social dialogue.

In the recent past, the ESC has failed to play a significant role due to lack of interest or conflict between its members. For example, no single meeting was held between May 2008 and September 2011. However, there have been some improvements in the last few years, especially following the new agreement of 2010. The ESC members started holding regular meetings. Nevertheless, in 2011 the government changed the Law on Employment and Unemployment Insurance without consulting social partners, although the law is subject to obligatory social dialogue (Anceva, 2012). There is thus some room for improvement in social dialogue in FYR Macedonia.

\section{Policy approach and measures adopted in FYR Macedonia}

Examining the scholarly literature on tackling undeclared work, there are two contrasting policy approaches (see Table 4). On the one hand, there is a dominant direct controls approach, which detects and punishes non-compliance and/or provides rewards for those engaging in compliant behaviour. The underlying premise is that people are rational 
actors who behave in a manner to maximise their expected utility. In other words, they disobey the law if the expected penalty and probability of detection is small relative to the profits gained. Based on this premise, governments must seek to deter these supposedly rational economic actors by making the benefits of non-compliance smaller than the benefits of compliance. To deter engagement therefore, the goal is to change the cost/benefit ratio facing those participating or considering participation in non-compliance (e.g., Allingham and Sandmo, 1972). In this deterrence approach, this is achieved by focusing on the cost side of the equation and increasing the actual and perceived risks and costs associated with participation by firstly, raising the perceived or actual likelihood of detection and/or secondly, raising the penalties and sanctions for those caught.

Table 4 Typology of policy approaches and measures for tackling the undeclared economy

\begin{tabular}{|c|c|c|}
\hline Approach & Method & Measures (examples) \\
\hline \multirow{6}{*}{$\begin{array}{l}\text { Direct controls: } \\
\text { deterrents }\end{array}$} & \multirow[t]{3}{*}{ Improved detection } & Data matching and sharing \\
\hline & & Joined up strategy \\
\hline & & Joint operations \\
\hline & Increased penalties & Increased penalties for evasion \\
\hline & \multirow[t]{2}{*}{ Increase perception of risk } & Advertising the penalties for undeclared work \\
\hline & & $\begin{array}{l}\text { Advertising the effectiveness of detection } \\
\text { procedures }\end{array}$ \\
\hline \multirow{6}{*}{$\begin{array}{l}\text { Direct controls: } \\
\text { incentives }\end{array}$} & \multirow[t]{4}{*}{ Preventative } & Simplification of compliance \\
\hline & & Direct and indirect tax incentives \\
\hline & & Supply chain responsibility \\
\hline & & Support and advice to start-ups \\
\hline & \multirow[t]{2}{*}{ Curative } & $\begin{array}{l}\text { Supply-side incentives (e.g., society-wide } \\
\text { amnesties; voluntary disclosure; smoothing } \\
\text { transition to formalisation) }\end{array}$ \\
\hline & & $\begin{array}{l}\text { Demand-side incentives (e.g., service vouchers; } \\
\text { targeted direct taxes; targeted indirect taxes) }\end{array}$ \\
\hline \multirow{7}{*}{$\begin{array}{l}\text { Indirect controls: } \\
\text { reduce asymmetry } \\
\text { between formal } \\
\text { and informal } \\
\text { institutions }\end{array}$} & \multirow{3}{*}{$\begin{array}{l}\text { Change informal } \\
\text { institutions } \\
\text { (values, norms and beliefs) }\end{array}$} & Tax education \\
\hline & & Normative appeals \\
\hline & & $\begin{array}{l}\text { Education and awareness raising of benefits of } \\
\text { declared work }\end{array}$ \\
\hline & \multirow{4}{*}{$\begin{array}{l}\text { Change formal institutions } \\
\text { (laws and regulations) }\end{array}$} & Procedural fairness \\
\hline & & Procedural justice \\
\hline & & Redistributive justice \\
\hline & & Wider economic and social developments \\
\hline
\end{tabular}

On the other hand, there is an emergent indirect controls approach. Its starting point is that where there is an institutional incongruity between the laws, codes and regulations of formal institutions and the norms, beliefs and codes of conduct of informal institutions, 
what formal institutions deem to be illegal activities are seen as legitimate in terms of the norms, values and codes of conduct of the society (De Castro et al., 2014; North, 1990; Webb et al., 2009, 2013, 2014; Williams and Vorley, 2014). To tackle the undeclared economy therefore, there is a need to reduce this institutional incongruence.

This can be achieved in two ways. Firstly, policy can seek to change the norms, values and codes of conduct of the population regarding the acceptability of undeclared work. This can be achieved using awareness raising campaigns about the costs of undeclared work and benefits of declared work, tax education campaigns and normative appeals. Secondly, policy can also seek to change the formal institutions to align with the norms, values and codes of conduct of informal institutions. On the one hand, this involves changing internal processes within the formal institutions to improve the perception that there is tax fairness, redistributive justice and procedural justice. Tax fairness here refers to the extent to which people believe they are paying their fair share compared with others (Wenzel, 2004). Redistributive justice refers to whether they receive the goods and services they believe that they deserve given the taxes that they pay (Richardson and Sawyer, 2001) and procedural justice to the degree to which they believe that the tax authority has treated then in a respectful, impartial and responsible manner (Braithwaite and Reinhart, 2000; Murphy, 2005). On the other hand, it involves changing the products of formal institutions by pursuing wider economic and social developments that engender a greater commitment of citizens to compliance (Williams, 2014c, 2014d).

\subsection{Policy approaches and measures in FYR Macedonia}

Table 5 reviews the implemented approaches and measures to tackle the problem of undeclared work in FYR Macedonia compared with 31 European countries. From this, it is evident that it is the direct controls approach which is dominant in FYR Macedonia and more particularly, a direct controls approach based on the use of deterrents (including penalties and measures related to improving detection). However, even here, there are gaps in policy provision. For example, there is no obligatory registration of workers prior to starting work (a practice in $74 \%$ of the other EU countries), which makes it difficult for labour inspectors to deal with the undeclared economy. When turning up to a workplace, an employer can simply claim that the worker has started work that day and has not yet been registered. In addition, a sector-specific approach is absent, except when it comes to targeted inspections in certain high-risk sectors. For example, more inspections could be used to target construction sites, hotels, restaurants, etc., as is the case in Romania, Latvia, Portugal and Sweden (Eurofound, 2013) or introducing an obligatory ID registration for workers in these sectors, as is the case in Belgium (Eurofound, 2013).

Turning to the incentive measures implemented, these policy measures tend to target the workforce which is about to enter the labour market so as to prevent undeclared work, while paying less attention to the formalisation (curative) of those already operating in the undeclared economy. Nevertheless, considerable progress has been made in some areas, such as reducing compliance costs for doing business and easing the tax burden through a number of supply-side measures, such as tax incentives, a flat-tax system, tax rate simplification, as well as simplified procedures for company registration and paying taxes. In the realm of introducing indirect controls, however, there has been very little progress. Indeed, such an approach and its accompanying measures are near enough entirely absent. 
Table 5 Policy measures used to tackle undeclared economy in FYR Macedonia compared with 31 European countries

\begin{tabular}{|c|c|c|}
\hline Policy measure & $\begin{array}{c}\text { Used in } \\
\text { FYR } \\
\text { Macedonia } \\
\end{array}$ & $\begin{array}{c}\% \text { of } 31 \\
\text { European nations } \\
\text { using measure }\end{array}$ \\
\hline \multicolumn{3}{|l|}{ Direct controls } \\
\hline Penalties & & 93 \\
\hline Administrative sanctions for purchasers/companies & $\checkmark$ & 87 \\
\hline Administrative sanctions for suppliers/employees & & 83 \\
\hline Penal sanctions for purchasers/companies & $\checkmark$ & 74 \\
\hline Penal sanctions for suppliers/employees & & 52 \\
\hline Measures to improve detection & & 100 \\
\hline Data matching and sharing & $\checkmark$ & 83 \\
\hline Workplace inspections & $\checkmark$ & 100 \\
\hline $\begin{array}{l}\text { Registration of workers prior to starting work or on first day } \\
\text { of work }\end{array}$ & & 74 \\
\hline Coordinating strategy across government & & 57 \\
\hline $\begin{array}{l}\text { Certification of business, certifying payments of social } \\
\text { contribution and taxes }\end{array}$ & & 65 \\
\hline Use of peer-to-peer surveillance (e.g., telephone hotlines) & $\checkmark$ & 39 \\
\hline Coordination of operations across government & & 61 \\
\hline Coordination of data sharing across government & $\checkmark$ & 65 \\
\hline Mandatory ID in the workplace & & 65 \\
\hline \multicolumn{3}{|l|}{ Measures enabling compliance: } \\
\hline Incentives: preventative measures & & 90 \\
\hline Reduce regulations & $\checkmark$ & 48 \\
\hline Simplify compliance procedures & $\checkmark$ & 87 \\
\hline Technological innovations (e.g., certified cash registers) & & 43 \\
\hline New categories of work (e.g., for small or mini-jobs) & & 35 \\
\hline Direct tax incentives (e.g., exemptions, deductions) & $\checkmark$ & 61 \\
\hline Social security incentives & $\checkmark$ & 35 \\
\hline Ease transition from unemployment into self-employment & $\checkmark$ & 65 \\
\hline Ease transition from employment into self-employment & & 44 \\
\hline Changing minimum wage upwards & $\checkmark$ & 48 \\
\hline Changing minimum wage downwards & & 9 \\
\hline Training and support to business start-ups & $\checkmark$ & 61 \\
\hline Micro-finance to business start-ups & $\checkmark$ & 52 \\
\hline Advice on how to formalise & & 61 \\
\hline Connecting pension schemes to formal labour & $\checkmark$ & 61 \\
\hline Introducing supply chain responsibility & & 17 \\
\hline Restricting free movement of (foreign) workers & & 43 \\
\hline
\end{tabular}

Source: Update of Williams et al. (2013a: Table 7) 
Table 5 Policy measures used to tackle undeclared economy in FYR Macedonia compared with 31 European countries (continued)

\begin{tabular}{|c|c|c|}
\hline Policy measure & $\begin{array}{l}\text { Used in } \\
\text { FYR } \\
\text { Macedonia }\end{array}$ & $\begin{array}{c}\% \text { of } 31 \\
\text { European nations } \\
\text { using measure }\end{array}$ \\
\hline \multicolumn{3}{|l|}{ Measures enabling compliance: } \\
\hline Incentives: curative measures & & 64 \\
\hline \multicolumn{3}{|l|}{ Stimulate purchasers to buy declared goods and services } \\
\hline Service vouchers & $\checkmark$ & 26 \\
\hline Targeted direct tax incentives & $\checkmark$ & 61 \\
\hline Targeted indirect taxes & & 17 \\
\hline \multicolumn{3}{|l|}{ Stimulate suppliers to formalise } \\
\hline Society-wide amnesties & & 9 \\
\hline Individual-level amnesties for voluntary disclosure & & 17 \\
\hline Formalisation advice to business & $\checkmark$ & 30 \\
\hline Formalisation support services to businesses & & 30 \\
\hline Targeted VAT reductions & & 17 \\
\hline Free record-keeping software to businesses & & 13 \\
\hline Fact sheets on record-keeping & & 22 \\
\hline Free advice/training on record-keeping & & 22 \\
\hline Gradual formalisation schemes & & 13 \\
\hline Indirect controls & & 69 \\
\hline $\begin{array}{l}\text { Campaigns to inform undeclared workers of risks and costs } \\
\text { of working undeclared }\end{array}$ & & 61 \\
\hline $\begin{array}{l}\text { Campaigns to inform undeclared workers of benefits of } \\
\text { formalising their work }\end{array}$ & & 57 \\
\hline $\begin{array}{l}\text { Campaigns to inform users of undeclared work of the risks } \\
\text { and costs }\end{array}$ & & 61 \\
\hline $\begin{array}{l}\text { Campaigns to inform users of undeclared work of the } \\
\text { benefits of declared work }\end{array}$ & $\checkmark$ & 52 \\
\hline Use of normative appeals to people to declare their activities & & 52 \\
\hline Measures to change perceived fairness of the system & & 26 \\
\hline $\begin{array}{l}\text { Measures to improve procedural justice of the system } \\
\text { (i.e., degree to which people believe government has treated } \\
\text { them in a respectful, impartial and responsible manner) }\end{array}$ & & 17 \\
\hline $\begin{array}{l}\text { Measures to improve knowledge of tax, social security and } \\
\text { labour law }\end{array}$ & $\checkmark$ & 65 \\
\hline $\begin{array}{l}\text { Adoption of commitment rather than compliance approach } \\
\text { (e.g., 'responsive regulation') }\end{array}$ & & 30 \\
\hline $\begin{array}{l}\text { Campaigns to encourage a culture of commitment to } \\
\text { declaration }\end{array}$ & & 39 \\
\hline
\end{tabular}

Source: Update of Williams et al. (2013a: Table 7) 
Table 6 FYR Macedonia 2014 National Action Plan to tackle the undeclared economy: responsible institutions and policy measures

\begin{tabular}{|c|c|}
\hline Responsible Institution & Planned actions for 2014 \\
\hline $\begin{array}{l}\text { MLSP and the Employment } \\
\text { Agency (enabling regular } \\
\text { employment): }\end{array}$ & $\begin{array}{l}\text { - Measures to improve regulations related to seasonal workers } \\
\text { and registered unemployed persons } \\
\text { - Subsidising the employment of social benefit recipients and } \\
\text { their potential employers } \\
\text { - Improving the regulation establishing jurisdiction for } \\
\text { determination of undocumented workers by the market } \\
\text { inspection and PRO } \\
\text { - Support for formalisation of undeclared work by } \\
\text { unemployed/unregistered businesses }\end{array}$ \\
\hline $\begin{array}{l}\text { Ministry of Finance and } \\
\text { Public Revenue Office } \\
\text { (increasing tax compliance): }\end{array}$ & $\begin{array}{l}\text { - National campaign for increasing citizens' tax morale and } \\
\text { public awareness of the benefits of paying taxes. }\end{array}$ \\
\hline $\begin{array}{l}\text { Ministry of Education and } \\
\text { Science (youth education): }\end{array}$ & $\begin{array}{l}\text { - Educating students in secondary school on the negative } \\
\text { effects of undeclared work }\end{array}$ \\
\hline $\begin{array}{l}\text { State Labour Inspectorate } \\
\text { (labour inspections and } \\
\text { control): }\end{array}$ & $\begin{array}{l}\text { - Strengthening inspection and control on a sectorial basis } \\
\text { - Strengthening cooperation between regional inspectors } \\
\text { - } \quad \text { Publishing a 'Black List' of firms with detected irregularities }\end{array}$ \\
\hline $\begin{array}{l}\text { Public Revenue Office } \\
\text { (tax revenue collection and } \\
\text { control): }\end{array}$ & $\begin{array}{l}\text { - } \quad \text { Detecting taxpayers performing undeclared work (with SLI) } \\
\text { - } \quad \text { Detecting taxpayers in temporary employment } \\
\text { - } \quad \text { Detecting undeclared taxable income of individual taxpayers } \\
\text { - } \quad \text { Implementing and monitoring the fiscal cash registers system }\end{array}$ \\
\hline $\begin{array}{l}\text { Customs Administration and } \\
\text { Ministry of Interior } \\
\text { (customs duties collection } \\
\text { and control): }\end{array}$ & $\begin{array}{l}\text { - Strengthening border control (legal and illegal border } \\
\text { passages) and determining customs duties payable } \\
\text { - Enhancing control over individuals crossing the borders } \\
\text { ('shuttle trade') }\end{array}$ \\
\hline $\begin{array}{l}\text { Ministry of Economy } \\
\text { (incl. State Market } \\
\text { Inspectorate, State } \\
\text { Inspectorate for Technical } \\
\text { Inspection, State } \\
\text { Inspectorate for Construction } \\
\text { and Urban Development } \\
\text { (market regulation): }\end{array}$ & $\begin{array}{l}\text { - Strengthening control over undeclared commercial activities } \\
\text { at restricted places (green markets, pavements and squares) } \\
\text { - Strengthening control over undeclared work in catering and } \\
\text { tourism } \\
\text { - Strengthening control over concessionaires performing } \\
\text { geological research and exploitation of mineral resources } \\
\text { - Regionalisation of the State Inspectorate for Technical } \\
\text { Inspection } \\
\text { - Strengthening control over marketed products in line with the } \\
\text { Law on Product Safety and the Law on Construction Products } \\
\text { - Strengthening control in relation to consumer rights } \\
\text { observance }\end{array}$ \\
\hline
\end{tabular}

Source: Non-exhaustive list of measures based on the national Action Plan for the reduction of the grey economy for 2014 (MLSP, 2014) 
There is little evidence, moreover, that this is changing. As Table 6 displays, in the most recent Action Plan for the reduction of the grey economy (Ministry of Economy, 2013; MLSP, 2014), the focus remains on the use of direct controls for tackling the undeclared economy. Although there is some move towards incentives within the direct controls approach, with for example the MLSP announcing in 2013 that it would implement innovative measures such as measures similar to the Belgian voucher system (ICF and GHK, 2013), the focus remains on direct controls in general and deterrence measures more particularly.

However, there are some signs of recognition that indirect controls which reduce the institutional incongruence between formal and informal institutions can be used to reduce the undeclared economy. The Ministry of Finance and Public Revenue Office has been given responsibility for organising a national campaign for increasing citizens' tax morale and their public awareness of the benefits of paying taxes in a bid to change the values, norms and codes of conduct of informal institutions so as to bring them into line with formal institutions. Nevertheless, the current Action Plan gives little or no explicit attention when tackling the undeclared economy to changing formal institutions in order to promote tax fairness, procedural justice and distributive justice, and there is no explicit recognition that wider economic and social developments may also have a significant impact on the size of the undeclared economy.

\section{Conclusions}

This paper has evaluated how the undeclared economy is being tackled in FYR Macedonia. Reporting the findings on the extent and nature of the undeclared economy in this country, it is revealed that FYR Macedonia has the largest undeclared economy of all European countries and such work is prevalent across all sectors of the economy and business types.

Examining how the undeclared economy is being tackled, it is revealed that there is currently no single agency with sole responsibility for tackling the undeclared economy. Instead, responsibility for different facets is fragmented across a range of government institutions, although akin to many other transition economies, the labour inspectorate has tended to take lead responsibility. One way forward therefore, is to establish a single agency or central committee to better coordinate the fight against undeclared work in FYR Macedonia.

To analyse the policy approaches and measures adopted in FYR Macedonia, this paper has differentiated between a dominant direct controls approach, which detects and punishes non-compliance and/or provides rewards for those engaging in compliant behaviour and an emergent indirect controls approach, which depicts undeclared to result from the asymmetry between the laws, codes and regulations of formal institutions and the norms, beliefs and values of informal institutions. To tackle the undeclared economy therefore, this seeks to change not only the informal institutions (e.g., using awareness raising campaigns, tax education and normative appeals) but also formal institutions (e.g., by pursuing tax fairness, procedural justice and redistributive justice, and wider economic and social developments), so as to align the formal and informal institutions.

Analysing the policy approaches and measures adopted in FYR Macedonia, this paper has revealed that policy remains entrenched in the pursuit of a direct controls approach in general, and one based on deterrence measures more particularly. Although there is now 
a shift towards using incentives to change the cost/benefit ratio, especially through the use of preventative measures, there is little attention being paid to curative measures. More widely, little consideration has so far been given to the policy measures advocated by the indirect controls approach. Although the 2014 Action plan has given responsibility to the Ministry of Finance and Public Revenue Office for organising a national campaign for increasing citizens' tax morale and their public awareness of the benefits of paying taxes in order to seek to change the values, norms and codes of conduct of informal institutions, little or no attention is being paid to changing formal institutions. On the one hand, this involves the implementation of changes to internal processes within formal institutions to improve the perception that there is tax fairness, procedural justice and redistributive justice. On the other hand, it involves changing the products of formal institutions by pursuing wider economic and social developments that engender a greater commitment of citizens to compliance. Previous studies reveal that this would require the creation of a more equal (as measured by the gini-coefficient) society in which there is greater labour market intervention to protect vulnerable groups, higher levels of social protection and more effective redistribution via social transfers (Williams, 2014a).

If this paper therefore encourages greater reflection in both FYR Macedonia and beyond on the range of policy approaches and measures being used when tackling undeclared work, and more particularly on the role that indirect controls measures might play, then it will have achieved its main policy-oriented intention. If it also leads to the wider recognition that it is the asymmetry between the codified laws and regulations of formal institutions and the values, norms and codes of conduct of informal institutions that determines the persistence of an undeclared economy, then it will have achieved its wider scholarly intention.

\section{Acknowledgements}

This paper is an output of the European Commission's Framework 7 Industry-Academia Partnerships Programme (IAPP) grant no. 611259 entitled "Out of the shadows: developing capacities and capabilities for tackling undeclared work in Bulgaria, Croatia and FYR Macedonia" (GREY). The authors would like to thank the funders for providing the financial support to enable this to be written. The usual disclaimers apply.

\section{References}

Ahmad, N. (2007) 'Measuring the non-observed economy in Western Balkan countries: practical lessons for transition economies', paper presented at the International Conference Experiences and Challenges in Measuring National Income and Wealth in Transition Economies, 18-21 September, Beijing, China [online] http://www.iariw.org/papers/2007/ahmad.pdf (accessed 18 May 2014).

Allingham, M.G. and Sandmo, A. (1972) 'Income tax evasion: a theoretical analysis', Journal of Public Economics, Vol. 1, No. 2, pp.323-338.

Anceva, M. (2012) Annual Review 2011 on Labour Relations and Social Dialogue in South East Europe: Macedonia, Friedrich-Ebert-Stiftung, Belgrade.

Braithwaite, V. and Reinhart, M. (2000) The Taxpayers' Charter: Does the Australian Tax Office Comply and Who Benefits, Centre for Tax System Integrity Working Paper no.1, Australian National University, Canberra. 
Dana, L-P. (1998) 'Waiting for direction in the former Yugoslaw Republic of Macedonia (FYROM)', Journal of Small Business Management, Vol. 36, No. 2, pp.62-67.

Dana, L-P. (2010) When Economies Change Hands: A Survey of Entrepreneurship in the Emerging Markets of Europe from the Balkans to the Baltic States, Routledge, Oxford.

Dana, L-P. (2013) 'Informal economy, entrepreneurship and policy implications', in Thai, M. and Turkina, E. (Eds.): Entrepreneurship in the Informal Economy: Models, Approaches and Prospects for Economic Development, pp.260-268, Routledge, London.

De Castro, J.O., Khavul, S. and Bruton, G.D. (2014) 'Shades of grey: how do informal firms navigate between macro and meso institutional environments?', Strategic Entrepreneurship Journal, Vol. 8, No. 1, pp.75-94.

Dekker, H., Oranje, E., Renooy, P., Rosing, F. and Williams, C.C. (2010) Joining Up the Fight against Undeclared Work in the European Union, DG Employment, Social Affairs and Equal Opportunities, Brussels.

Dzhekova, R. and Williams, C.C. (2014) Tackling Undeclared Work in Bulgaria: A Baseline Report, GREY Working Paper no. 1, Sheffield University Management School, University of Sheffield, Sheffield.

Elgin, C. and Öztunali, O. (2012) Shadow Economies around the World: Model Based Estimates, Bogazici University, Department of Economics, Istanbul.

Eurofound (2012) Former Yugoslav Republic of Macedonia (FYROM): Industrial Relations Profile, Eurofound, Dublin.

Eurofound (2013) Tackling Undeclared Work in 27 European Union Member States and Norway: Approaches and Measures since 2008, Eurofound, Dublin.

European Commission (2007) Stepping Up the Fight Against Undeclared Work, European Commission, Brussels.

Franic, J. and Williams, C.C. (2014) Undeclared Work in Croatia: A Baseline Assessment, GREY Working Paper no. 2, Sheffield University Management School, University of Sheffield, Sheffield.

Gallin, D. (2001) 'Propositions on trade unions and informal employment in time of globalisation', Antipode, Vol. 19, No. 4, pp.531-549.

Garvanlieva, V., Andonov, V. and Nikolov, M. (2012) Shadow Economy in Macedonia, Center for Economic Analyses, Skopje.

Hudson, J., Williams, C.C., Orviska, M. and Nadin, S. (2012) 'Evaluating the impact of the informal economy on business in South East Europe: some lessons from the 2009 World Bank Enterprise Survey', South East European Journal of Economics and Business, Vol. 7, No. 1, pp.99-110.

ICF and GHK (2013) European Employment Observatory Quarterly Reports, Catalogue of measures, 1st Quarter of 2013, January-March, European Employment Observatory [online] http://www.eu-employment-observatory.net/resources/quarterly_reports_exec_summary/ QRESCatalogueOfMeasures-Apr2013.pdf (accessed 14 May 2014).

International Labour Organisation (2011) Labour Inspection Country Profile: The Former Yugoslav Republic of Macedonia, ILO, Geneva [online] http://www.ilo.org/labadmin/info/ WCMS_114938/lang--en/index.htm (accessed 20 May 2014).

International Labour Organisation (2012) Statistical Update on Employment in the Informal Economy, ILO, Geneva.

Ministry of Economy, Republic of Macedonia (2013) Presented Action Plan for Reduction of the Informal Economy for 2013, 21 February, Ministry of Economy, Skopje [online] http://www.economy.gov.mk/EN/ministria/3382.html (accessed 12 May 2014).

Ministry of Labour and Social Policy (MLSP) (2014) Информација со Акциики план за намалување на сивата економија во Република Македонија за 2014 година. [Action Plan for the reduction of the grey economy in the Republic of Macedonia for 2014], MLSP, Skopje [online] http://www.mtsp.gov.mk/dokumenti.nspx (accessed 30 May 2014). 
Murphy, K. (2005) 'Regulating more effectively: the relationship between procedural justice, legitimacy and tax non-compliance', Journal of Law and Society, Vol. 32, No. 4, pp.562-589.

North, D.C. (1990) Institutions, Institutional Change and Economic Performance, Cambridge University Press, Cambridge.

Novkovska, B. (2008) 'Measuring non-standard and informal employment in the Republic of Macedonia', paper presented at the Workshop Measurement Informal Employment in Developed Countries WIEGO, 31 October-1 November, Kennedy School of Government, Harvard University.

Novkovska, B. (2013) 'Defining and measuring non-standard and informal employment in the agricultural sector', paper presented at the Sixth International Conference on Agricultural Statistics.

OECD (2002) Measuring the Non-Observed Economy, OECD, Paris.

Rezaei, S., Goli, M. and Dana, L-P. (2013a) 'An empirical study of the underground economy in the Kingdom of Belgium', International Journal of Business and Globalisation, Vol. 11, No. 2, pp.159-170.

Rezaei, S., Goli, M. and Dana, L-P. (2013b) 'Informal opportunity among SMEs: an empirical study of Denmark's underground economy', International Journal of Entrepreneurship and Small Business, Vol. 19, No. 1, pp.64-76.

Rezaei, S., Goli, M. and Dana, L-P. (2014) 'Beyond legal entrepreneurship: the case of Austria', International Journal of Entrepreneurship and Small Business, Vol. 21, No. 2, pp.202-215.

Richardson, M. and Sawyer, A. (2001)'A taxonomy of the tax compliance literature: further findings, problems and prospects', Australian Tax Forum, Vol. 16, No. 2, pp.137-320.

Risteski, H. (2009) Assessing Handicraft Shadow Economy in Macedonia, CEA, Skopje.

Schneider, F., Buehn, A. and Montenegro, C. (2010) Shadow Economies All over the World, New Estimates for 162 Countries from 1999 to 2007. Policy Research Working Paper 5356, World Bank, Washington DC.

Stankovic, M. and Stankovic, B. (2012) 'Social and economic aspects of the shadow economy in the Republic of Macedonia: a study', Social Science Research Network [online] http://ssrn.com/abstract=2162922 (accessed 20 May 2014).

State Statistical Office (2013) Labour Force Survey 2012, State Statistical Office, Skopje.

Tevdoski, D. (2011) Decent Work in the Republic of Macedonia, Progress Institute, Palme Center and SOLIDAR [online] http://www.palmecenter.org/PageFiles/62765/Decent\%20Work\%20in\%20the\%20Republic\%2 0of\%20Macedonia.pdf (accessed 18 June 2014).

UNECE (2008) Non-Observed Economy in National Accounts: Survey of Country Practices, United Nations, Geneva.

Vanderseypen, G., Tchipeva, T., Peschner, J., Renooy, P. and Williams, C.C. (2013) 'Undeclared work: recent developments', in European Commission (Ed.): Employment and Social Developments in Europe 2013, pp.231-274, European Commission, Brussels.

Webb, J.W., Bruton, G.D., Tihanyi, L. and Ireland, R.D. (2013) 'Research on entrepreneurship in the informal economy: framing a research agenda', Journal of Business Venturing, Vol. 28, No. 5, pp.598-614.

Webb, J.W., Ireland, R.D. and Ketchen, D.J. (2014) 'Towards a greater understanding of entrepreneurship and strategy in the informal economy', Strategic Entrepreneurship Journal, Vol. 8, No. 1, pp.1-15.

Webb, J.W., Tihanyi, L., Ireland, R.D. and Sirmon, D.G. (2009) 'You say illegal, I say legitimate: entrepreneurship in the informal economy', Academy of Management Review, Vol. 34, No. 3, pp.492-510.

Wenzel, M. (2004) 'An analysis of norm processes in tax compliance', Journal of Economic Psychology, Vol. 25, No. 2, pp.213-228. 
Williams, C.C. (2007a) 'Socio-spatial variations in the nature of entrepreneurship', Journal of Enterprising Communities, Vol. 1, No. 1, pp.27-37.

Williams, C.C. (2007b) 'The nature of entrepreneurship in the informal sector: evidence from England', Journal of Developmental Entrepreneurship, Vol. 12, No. 2, pp.239-254.

Williams, C.C. (2009) 'Formal and informal employment in Europe: beyond dualistic representations', European Urban and Regional Studies, Vol. 16, No. 2, pp.147-159.

Williams, C.C. (2011) 'Entrepreneurship, the informal economy and rural communities', Journal of Enterprising Communities, Vol. 5, No. 2, pp.145-157.

Williams, C.C. (2013a) 'Beyond the formal economy: evaluating the level of employment in informal sector enterprises in global perspective', Journal of Developmental Entrepreneurship, Vol. 18, No. 4, pp.1-21, doi: 10.1142/S1084946713500271.

Williams, C.C. (2013b) 'Evaluating the cross-national variations in under-declared wages in the European Union: an exploratory study', The Open Area Studies Journal, Vol. 5, pp.12-21

Williams, C.C. (2014a) 'Out of the shadows: a classification of economies by the size and character of their informal sector', Work, Employment and Society, doi: 10.1177/0950017013501951.

Williams, C.C. (2014b) 'Uncoupling enterprise culture from capitalism: some lessons from Moscow', Journal of Enterprising Communities, Vol. 8, No. 2, pp.111-125.

Williams, C.C. (2014c) Confronting the Shadow Economy: Evaluating Tax Compliance Behaviour and Policies, Edward Elgar, Cheltenham.

Williams, C.C. (2014d) Policy approaches towards undeclared work: a conceptual framework, GREY Working Paper no. 4, Sheffield University Management School, University of Sheffield, Sheffield.

Williams, C.C. (2014e) The Informal Economy and Poverty: Evidence and Policy Review, Report prepared for Joseph Rowntree Foundation, New York.

Williams, C.C. and Gurtoo, A. (2013) 'Beyond entrepreneurs as heroic icons of capitalism: a case study of street entrepreneurs in India', International Journal of Entrepreneurship and Small Business, Vol. 19, No. 4, pp.421-437.

Williams, C.C. and Lansky, M. (2013) 'Informal employment in developed and emerging economies: perspectives and policy responses', International Labour Review, Vol. 152, Nos. 3-4, pp.355-380.

Williams, C.C. and Martinez-Perez, A. (2014a) 'Do small business start-ups test-trade in the informal economy? evidence from a UK small business survey', International Journal of Entrepreneurship and Small Business, Vol. 22, No. 1, pp.1-16.

Williams, C.C. and Martinez-Perez, A. (2014b) 'Explaining cross-national variations in tax morality in the European Union: an exploratory analysis', Studies in Transition States and Societies, Vol. 6, No. 2, pp.5-18.

Williams, C.C. and Martinez-Perez, A. (2014c) 'Is the informal economy an incubator for new enterprise creation? A gender perspective', International Journal of Entrepreneurial Behaviour and Research, Vol. 20, No. 1, pp.4-19.

Williams, C.C. and Martinez-Perez, A. (2014d) 'Why do consumers purchase goods and services in the informal economy?', Journal of Business Research, Vol. 67, No. 5, pp.802-806.

Williams, C.C. and Nadin, S. (2011a) 'Re-reading entrepreneurship in the hidden economy: commercial or social entrepreneurs?', International Journal of Entrepreneurship and Small Business, Vol. 14, No. 4, pp.441-455.

Williams, C.C. and Nadin, S. (2011b) 'Theorising the hidden enterprise culture: the nature of entrepreneurship in the shadow economy', International Journal of Entrepreneurship and Small Business, Vol. 14, No. 3, pp.334-348.

Williams, C.C. and Padmore, J. (2013a) 'Envelope wages in the European Union', International Labour Review, Vol. 152, Nos. 3-4, pp.411-430. 
Williams, C.C. and Padmore, J. (2013b) 'Evaluating the prevalence and distribution of quasiformal employment in Europe', Relations Industrielles/Industrial Relations, Vol. 68, No. 1, pp.71-95.

Williams, C.C. and Round, J. (2007) 'Entrepreneurship and the informal economy: a study of Ukraine's hidden enterprise culture', Journal of Developmental Entrepreneurship, Vol. 12, No. 1, pp.119-136.

Williams, C.C. and Round, J. (2009) 'Evaluating informal entrepreneurs' motives: some lessons from Moscow', International Journal of Entrepreneurial Behaviour and Research, Vol. 15, No. 1, pp.94-107.

Williams, C.C. and Round, J. (2010) 'Spatial variations in the character of off-the-books entrepreneurship: lessons from a study of contrasting districts in Moscow', International Journal of Entrepreneurship and Small Business, Vol. 10, No. 2, pp.287-301.

Williams, C.C. and Youssef, Y. (2014) 'Classifying Latin American economies: a degrees of informalisation approach', International Journal of Business Administration, Vol. 5, No. 3, pp.73-85.

Williams, C.C., Baric, M. and Renooy, P. (2013a) Tackling Undeclared Work in FYR Macedonia, Eurofound, Dublin.

Williams, C.C., Nadin, S., Newton, S., Rodgers, P. and Windebank, J. (2013b) 'Explaining off-the-books entrepreneurship: a critical evaluation of competing perspectives', International Entrepreneurship and Management Journal, Vol. 9, No. 3, pp.447-463.

Williams, C.C., Round, J. and Rodgers, P. (2010) 'Explaining the off-the-books enterprise culture of Ukraine: reluctant or willing entrepreneurship?', International Journal of Entrepreneurship and Small Business, Vol. 10, No. 2, pp.165-180.

Williams, N. and Vorley, T. (2014) 'Institutional asymmetry: how formal and informal institutions affect entrepreneurial behaviour in Bulgaria', International Small Business Journal, doi: $10.1177 / 0266242614534280$.

World Bank (2013) Doing Business 2014: Understanding Smarter Regulations for Small and Medium-Size Enterprises, Regional profile: European Union (EU), World Bank, Washington DC.

World Bank (2014) Enterprise Survey 2013, Country Profile Macedonia, World Bank, Washington DC. 